THE IBERO-AMERICAN BAROQUE 
This page intentionally left blank 


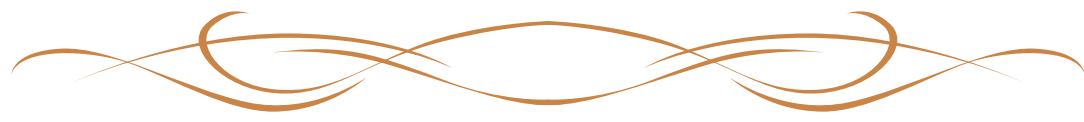

\section{The IBERO-AMERICAN}

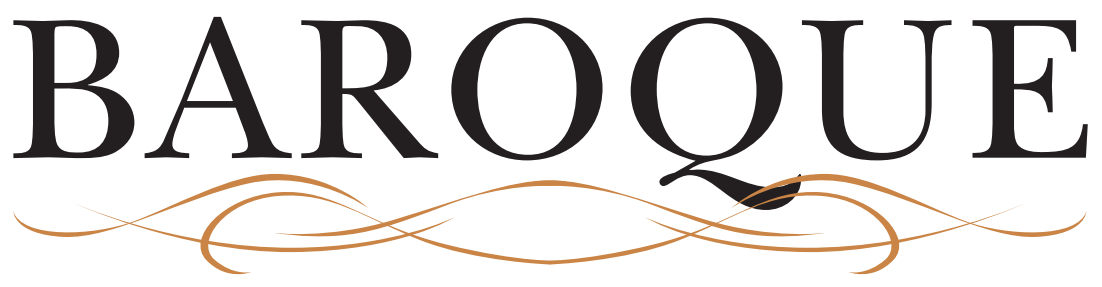

Edited by Beatriz de Alba-Koch 
(C) University of Toronto Press 2022

Toronto Buffalo London

utorontopress.com

Printed in the U.S.A.

ISBN 978-1-4426-4883-8 (cloth)

ISBN 978-1-4426-1 884-8 (EPUB)

ISBN 978-1-4426-1883-1 (PDF)

Toronto Iberic

\section{Library and Archives Canada Cataloguing in Publication}

Title: The Ibero-American Baroque / edited by Beatriz de Alba-Koch.

Names: De Alba-Koch, Beatriz, 1957- editor.

Series: Toronto Iberic.

Description: Series statement: Toronto Iberic | Includes

bibliographical references and index.

Identifiers: Canadiana (print) 2021028725X | Canadiana (ebook)

20210287322 | ISBN 9781442648838 (cloth) | ISBN 9781442618848

(EPUB) | ISBN 9781442618831 (PDF)

Subjects: LCSH: Civilization, Baroque - Latin America. |

LCSH: Latin America - Intellectual life. |

LCSH: Latin America - Civilization - European influences.

Classification: LCC F1412.I24 2022 | DDC 980/.013-dc23

We wish to acknowledge the land on which the University of Toronto Press operates. This land is the traditional territory of the Wendat, the Anishnaabeg, the Haudenosaunee, the Métis, and the Mississaugas of the Credit First Nation.

University of Toronto Press acknowledges the financial support of the Government of Canada, the Canada Council for the Arts, and the Ontario Arts Council, an agency of the Government of Ontario, for its publishing activities.
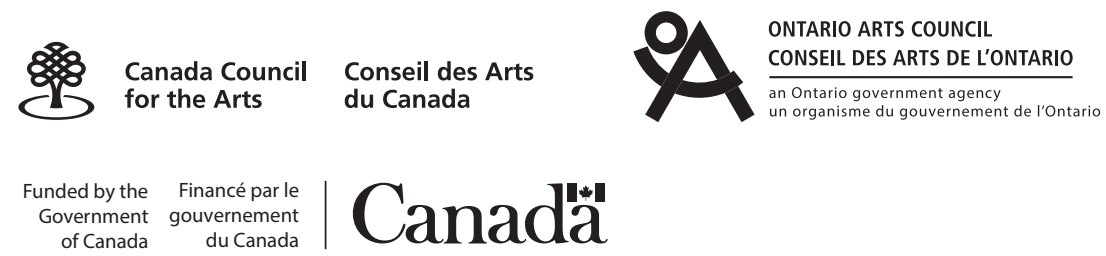
Em memória de Luís de Moura Sobral, estimado colega e querido amigo 
This page intentionally left blank 